4 Campbell DJ. Tissue renin-angiotensin system: sites of angiotensin formation. f Cardiovasc Pharmacol 1987;10 (suppl 7):S1-8

5 Kifor I, Dzau VJ. Endothelial renin-angiotensin pathway: evidence for intracellular synthesis and secretion of angiotensins. Circ Res 1987;60: 422-8.

16 Oliver JA, Sciacca RR. Local generation of angiotensin II as a mechanism of regulation of peripheral vascular tone in the rat. $\mathcal{F}$ Clin Invest 1984;74: 1247-51.

17 Saito H, Nakamura M, Ogihar T, et al. Renin inhibitor and converting enzyme inhibitors suppress vascular angiotensin II. Hypertension 1989;13: $749-53$.

18 Wood JM, Gulati N, Forgiarini P, Fuhrer W, Hofbauer KG. Effects of a specific and long-acting renin inhibitor in the marmoset. Hypertension 1985;7:797-803.
19 Pals DT, Thaisrivongs S, Lawson JA, et al. An orally active inhibitor of renin Hypertension 1986;8:1 105-6.

20 Kleinert HD, Martin D, Chekal MA, et al. Cardiovascular actions of the primate-selective renin inhibitor A 62198. I Pharmacol Exp Ther 1988;264 $975-9$

21 Verburg KM, Kleinert HD, Kadam JRC, Chekal MA, Mento PF, Wilkes BM. Effects of chronic infusion of renin inhibitor A-64662 in sodium depleted monkeys. Hypertension 1989;13:262-72.

22 Mann S, Millar Craig MW, Balasubramanian V, Cashman PMM, Raftery EB. Ambulant blood pressure: reproducibility and the assessment of interventions. Clin Sci 1980;59:497-500.

(Accepted 23 May 1990)
Department of Infectious Diseases, Rigshospitalet and Institute of Cancer Epidemiology, Danish Cancer Registry, Copenhagen, Denmark Mads Melbye, MD, senior epidemiologist

\section{Environmental} Epidemiology Branch, National Cancer Institute, National Institutes of Health, Bethesda, Maryland, United States Robert J Biggar, MD, professor in epidemiology

Blood Bank, Rigshospitalet, Copenhagen, Denmark Per Wantzin, MD, registrar in immunology

\section{Department of}

Rheumatology, Hvidovre

Hospital, Copenhagen, Denmark

Kim Krogsgaard, MD, registrar in internal medicine

Department of Virus and Cancer, Danish Cancer Society, Aarhus, Denmark Peter Ebbesen, MD, chief of department

Department of Statistics, La Trobe University, Bundoora, Victoria,

Australia

Niels G Becker, PHD,

professor in statistics

Correspondence and requests for reprints to: $\mathrm{Dr}$ $M$ Melbye, Department of Infectious Diseases, Rigshospitalet, Tagensvej 20, 2200 Copenhagen $N$, Denmark.

BrMed f 1990;301:210-2

\title{
Sexual transmission of hepatitis $C$ virus: cohort study (1981-9) among European homosexual men
}

\author{
Mads Melbye, Robert J Biggar, Per Wantzin, Kim Krogsgaard, Peter Ebbesen, \\ Niels G Becker
}

Abstract

Objective-To determine the prevalence, incidence, and persistence of positivity for antibodies to hepatitis $\mathrm{C}$ virus (anti-HCV) and the potential for sexual transmission of the virus.

Design-A cohort analysis covering 1981-9 comparing estimated cumulative incidences of and seroconversion rates for anti-HCV with those of hepatitis B core antibody (anti-HBc) and antibodies to the human immunodeficiency virus (anti-HIV).

Setting-Copenhagen and Aarhus, Denmark.

Subjects-259 Male members of a Danish homosexual organisation.

Main outcome measures-Correlations of prevalence and incidence with a wide range of sexual lifestyle variables.

Results-Only four (1.6\%) subjects were positive for anti-HCV in 1981. The estimated cumulative incidence of positivity for anti-HCV was $4 \cdot 1 \%$ in 1984 (seroconversion rate during 1981-4 (2.5\%)) and remained at $4 \cdot 1 \%$ in 1989 (seroconversion rate nil during 1984-9). In contrast, positivity for anti-HBC rose from $44.0 \%$ in 1981 to $52.7 \%$ in 1984 (seroconversion rate $15.5 \%$ ) and $58.8 \%$ in 1989 (serconversion rate $12.9 \%$ ), and that for anti-HIV rose from $8.8 \%$ to $24.0 \%$ (seroconversion rate $16.7 \%$ ) and $30 \cdot 1 \%$ (seroconversion rate $8.0 \%$ ) respectively. Three anti-HCV positive patients seroreverted three to five years later. None of the anti-HCV positive subjects had had a transfusion and only one gave a past history of intravenous drug use. Variables in sexual lifestyle correlated with the presence of antiHBc but not with that of anti-HCV.

Conclusions - In contrast with hepatitis B virus and HIV, sexual transmission of hepatitis $C$ virus seems to be a rare event. Furthermore, antibodies to the virus may become undetectable after several years.

\section{Introduction}

Although the classification and early descriptions of clinical non-A non-B hepatitis were derived primarily from cases associated with transfusion, this mode of transmission has recently been estimated to account for only $5-10 \%$ of patients with the disease in the developed world. ${ }^{1}$ In a substantial proportion of cases no obvious route or source of transmission is found. In this respect, therefore, the importance of sexual transmission has been an open question. A possibility for better understanding has emerged with the molecular cloning of an agent designated hepatitis $C$ virus, which seems responsible for most cases of parenteral non-A non- $B$ hepatitis. ${ }^{23}$ To date frequent transmission of hepatitis $\mathrm{C}$ virus by exposure to blood has been described in drug addicts and patients with haemophilia ${ }^{48}$ whereas little has been reported on the frequency of sexual transmission of the virus. We have studied the prevalence and persistence of antibodies to hepatitis $\mathrm{C}$ virus among homosexual men and analysed their possible association with a range of lifestyle factors to see if there is evidence for homosexual spread of hepatitis $C$ virus. Comparison was made with two other viral agents known to be frequently transmitted sexually - namely, hepatitis B virus ${ }^{9}$ and HIV. ${ }^{10}$

\section{Subjects and methods}

We studied a cohort of Danish homosexual men who had been followed up since 1981. ${ }^{111}$ Briefly, 259 subjects were initially enrolled from volunteers belonging to a national organisation of homosexual men. At enrolment their average age was 32.0 years, their average duration of homosexual activity $12 \cdot 2$ years, and their average number of partners 24.9 a year. Cross sectional analyses were performed on all subjects comparing antibody state with lifestyle and demographic variables. In addition, longitudinal studies were done on subjects who subsequent to the 1981 visit were also seen in 1984 or 1989 , or in both years. Compared with the original 1981 cohort members of this subset were slightly more experienced sexually (1984, 13.3 years of homosexual activity; 1989, 14.0 years) but otherwise were similar.

A log linear model was used to compute the nonparametric maximum likelihood estimate of the survival curves (1-estimated cumulative antibody incidence) from interval censored data, as detailed elsewhere. ${ }^{12}$ We also calculated the seroconversion rates between years of testing using the same methodology. Associations between serological markers and variables in lifestyle were analysed by Spearman rank order correlations and linear regressions.

Serum samples were kept frozen at $-70^{\circ} \mathrm{C}$ until assay and had not previously been thawed. All serum samples were tested for antibodies to hepatitis $C$ virus (anti-HCV) by an enzyme linked immunosorbent assay (ELISA; Ortho Diagnostic Systems). Samples that were non-reactive to hepatitis $C$ virus in the initial run were considered to be anti-HCV negative. Samples that were reactive to hepatitis $C$ virus were retested and considered to be positive if reactive in both tests. Exposure to hepatitis $B$ was determined by an assay for antibodies to hepatitis B core antigen (anti-HBc; CORZYME, Abbott Laboratories). This marker does not recognise patients immunised by vaccination. 
Testing for HIV antibody (anti-HIV) was performed by an indirect second generation ELISA with western blot for confirmation.

\section{Results}

HEPATITIS C VIRUS

Of the 259 subjects in the original cohort, 250 $(96.5 \%)$ had serum remaining for hepatitis tests. In 1981 four $(1.6 \%)$ of these men were positive for antiHCV. Three others seroconverted between 1981 and 1984 and one between 1981 and 1989 (table I). Using a log linear model we found the cumulative (since 1981) incidence of positivity for anti-HCV to be $4 \cdot 1 \%$ in 1984 and also $4 \cdot 1 \%$ in 1989 (table II). This analysis included anti-HCV positive subjects who later seroreverted.

Two of the three men who seroconverted to hepatitis $C$ virus between 1981 and 1984 also seroconverted to HIV during that period. By 1989 these two subjects were profoundly immunosuppressed (CD4 to CD8 ratios 0.20 and 0.04 ) and one had lost antibody to hepatitis $\mathrm{C}$ virus. The third seroconverter was antiHIV negative throughout, yet had also lost reactivity to hepatitis $\mathrm{C}$ virus by 1989.

None of the subjects on whom information was available had ever received a transfusion, and only one had ever used drugs intravenously (table I). Neither age, duration of homosexual activity, type of sexual activity, treatment for venereal disease, nor HIV state was significantly correlated with being anti-HCV positive (figure). The few anti-HCV positive subjects, however, tended to have more partners than seronegative subjects.

\section{HEPATITIS B VIRUS AND HIV}

Table II summarises the data on hepatitis and HIV. Anti-HBc was found in an estimated $44.0 \%$ of the men in $1981,52.7 \%$ in 1984 , and $58.8 \%$ in 1989 . In 1981 being positive for anti-HBc was correlated with numbers of sexual partners a year $(p<0 \cdot 0001)$, older age $(\mathrm{p}<0.0001)$, years of homosexual activity $(\mathrm{p}<0.0001)$, number of previous treatments for gonorrhoea and syphilis $(\mathrm{p}<0.0001)$, and also being seropositive to HIV $(p<0 \cdot 2)$ or seroconverting later $(\mathrm{p}<0.03)$ (figure). In logistic regression analyses the strongest single variable was number of partners (in all models $\mathrm{p}<0.0001$ ). In a model with the number of
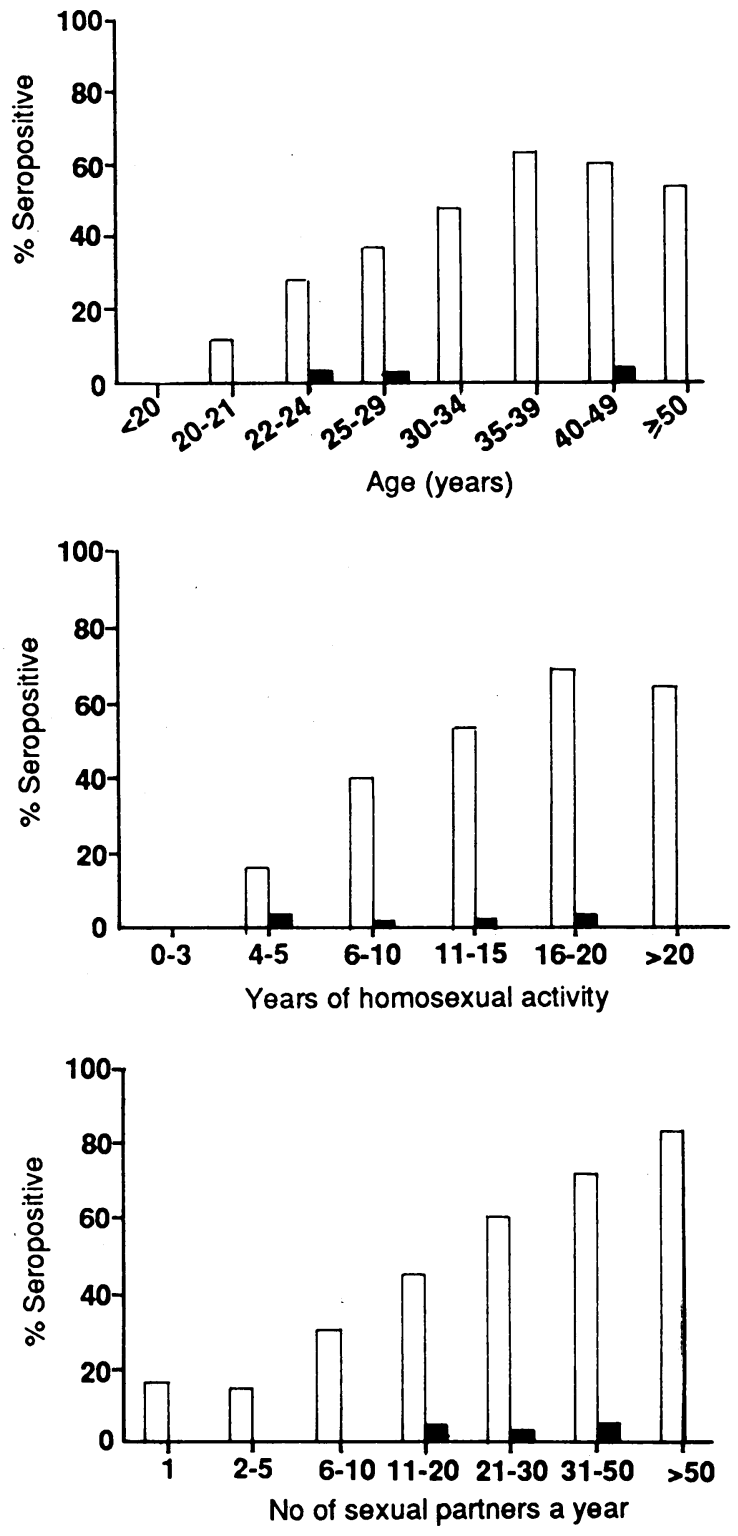

Correlates of positivity for anti-HBc ( $\square)$ and anti-HCV (ם) with age, years of homosexual activity, and numbers of sexual partners a year among cohort of Danish homosexual men (1981 data)

TABLE I-Presentation of subjects positive for hepatitis $C$ marker

\begin{tabular}{|c|c|c|c|c|c|c|c|}
\hline \multirow[b]{2}{*}{ Case No } & \multirow[b]{2}{*}{ Year of birth } & \multicolumn{3}{|c|}{ Serological results in 1981,1984 , and $1989^{\star}$} & \multirow{2}{*}{$\begin{array}{c}\text { Blood transfusion } \\
\text { evert }\end{array}$} & \multirow{2}{*}{$\begin{array}{c}\text { Intravenous drug } \\
\text { use evert }\end{array}$} & \multirow{2}{*}{$\begin{array}{c}\text { Clinical hepatitis } \\
\text { (year) }\end{array}$} \\
\hline & & Anti-HCV & Anti-HBc & HBsAg & & & \\
\hline 1 & 1939 & $+t+$ & $++t$ & --- & No & No & ?\| \\
\hline 2 & 1956 & $++t$ & --+ & NN- & No & No & No \\
\hline 3 & 1952 & +-- & --+ & $\mathrm{NN}-$ & No & No & $1977 \ddagger$ \\
\hline $4 !$ & 1959 & $+\mathrm{NN}$ & $-\mathrm{NN}$ & NNN & ?\| & No & No \\
\hline 5 & 1958 & -++ & +++ & --- & No & No & 1977 \\
\hline 6 & 1944 & -+- & +++ & --- & No & Yes & No \\
\hline 7 & 1949 & -+- & -++ & $\mathrm{N}++$ & No & No & 1984 \\
\hline 8 & 1930 & $-\mathrm{N}+$ & $+\mathrm{N}+$ & $-\mathrm{N}-$ & No & No & No \\
\hline
\end{tabular}

TABLE II - Estimated seroconversion rates and cumulative incidence of positivity for antibodies to hepatitis $C$ virus, hepatitis $B$ virus, and HIV in a cohort of homosexual men during 1981-9 (analyses include subjects who later seroreverted)

\begin{tabular}{|c|c|c|c|c|c|c|}
\hline \multirow[b]{2}{*}{ Year of testing ${ }^{\star}$} & \multicolumn{2}{|c|}{ Anti-HCV } & \multicolumn{2}{|c|}{ Anti-HBc } & \multicolumn{2}{|c|}{ Anti-HIV } \\
\hline & $\begin{array}{c}\text { Cumulative \% } \\
\text { positivity }\end{array}$ & $\begin{array}{c}\text { Seroconversion rate } \\
(\%)(95 \% \text { confidence } \\
\text { interval })\end{array}$ & $\begin{array}{c}\text { Cumulative \% } \\
\text { positivity }\end{array}$ & $\begin{array}{c}\text { Seroconversion rate } \\
(\%)(95 \% \text { confidence } \\
\text { interval })\end{array}$ & $\begin{array}{c}\text { Cumulative } \% \\
\text { positivity }\end{array}$ & $\begin{array}{c}\text { Seroconversion rate } \\
(\%)(95 \% \text { confidence } \\
\text { interval })\end{array}$ \\
\hline 1981 & $1 \cdot 6$ & \multirow[b]{2}{*}{$2 \cdot 5(0$ to $5 \cdot 0)$} & $44 \cdot 0$ & \multirow[b]{2}{*}{$15 \cdot 5(7 \cdot 4$ to $22 \cdot 9)$} & $8 \cdot 8$ & \multirow{3}{*}{$\begin{array}{l}16 \cdot 7(10 \cdot 8 \text { to } 22 \cdot 2) \\
8 \cdot 0(2 \cdot 7 \text { to } 13 \cdot 0)\end{array}$} \\
\hline 1984 & $4 \cdot 1$ & & $52 \cdot 7$ & & $24 \cdot 0$ & \\
\hline 1989 & $4 \cdot 1$ & 0 & $58 \cdot 8$ & $12 \cdot 9(3 \cdot 2$ to $21 \cdot 5)$ & $30 \cdot 1$ & \\
\hline
\end{tabular}

$\star 250$ Subjects tested in $1981 ; 122$ tested in 1981 and $1984 ; 112$ tested in 1981 and $1989 ; 73$ tested in all three years. 
partners held constant, years of homosexual activity but not age was also significant $(p=0 \cdot 0002)$. Number of episodes of venereal disease remained significantly associated even after adjustment for the number of partners. Two subjects were initially anti-HBc positive but seroreverted between 1984 and 1989. Both were anti-HIV positive and had abnormal CD4 to $\mathrm{CD} 8$ ratios $(0.04$ and $0 \cdot 17)$ with low $\mathrm{CD} 4$ values in 1989 .

\section{Discussion} a wide range of sexual lifestyle variables indicates that hepatitis B is a sexually transmitted disease among homosexual men. We have analysed these variables in detail in order to contrast the findings with reactivity to hepatitis $C$ virus. Had hepatitis $C$ been readily transmitted sexually we should expect to have seen a characteristic epidemiological profile. We found no direct evidence of sexual transmission of hepatitis C. Nevertheless, although few of our cohort of homosexual men were positive for anti-HCV, the proportion was considerably higher than that among male blood donors $(0.3 \%)$ of the same age in Denmark (Wantzin et $a l$, unpublished data). Yet none of our anti-HCV positive subjects had ever received a transfusion and only one gave a history of intravenous drug use. The absence of parenteral exposure favours the possibility of sexual transmission, although at a much lower rate than in the case of hepatitis B virus or HIV. Rates of seroconversion detected to hepatitis $C$ virus were six to 13 times lower than those recorded to hepatitis $B$ virus and HIV.

One caveat arose from the longitudinal data: the hepatitis $\mathrm{C}$ marker was not consistently present among all initially reactive or seroconverting subjects. Loss of with resolving non-A non-B hepatitis in a prospective study of transfusion recipients. ${ }^{13}$ We have reported declines in reactivity to hepatitis B virus, sometimes to undetectable levels, with progressive immunodeficiency ${ }^{14}$ and also observed the phenomenon with anti-HBc in this study. Not all subjects who lost reactivity to hepatitis $C$ virus in this study were infected with HIV and had abnormal immunity, however, which argues for a different explanation for the phenomenon of seroreversion to hepatitis $C$ virus.

Our observation that seroreversion to hepatitis $\mathrm{C}$ virus may be fairly common suggests that the cumulative incidence of seropositivity for the period 1981-9 may have been slightly higher than the $4 \cdot 1 \%$ recorded in this study. Alter et al, however, found the mean duration of anti-HCV positivity among subjects
The profile of an association between hepatitis B and anti-HCV has also been described in three patients

who later seroreverted to be $4 \cdot 1$ years (range 7 months to 11 years).${ }^{13}$ Hence the number of anti-HCV positive subjects missed in our series was probably small.

The persistence of reactivity in some subjects may indicate that some of these men were chronic carriers of hepatitis $\mathrm{C}$. Although a test for hepatitis $\mathrm{C}$ virus in the blood is not available, we note that the highest figures for the prevalence of circulating anti-HCV are reportedly found among patients with chronic non-A non-B hepatitis and that among these patients seroreversion is unlikely to occur. ${ }^{13}$ The high prevalence of anti-HCV in patients with haemophilia and intravenous drug users $^{4-8}$ may be explained by these people being chronic carriers or recurrently exposed to hepatitis C virus.

We conclude that hepatitis $\mathrm{C}$ virus is not readily spread by homosexual activity, although sexual transmission may occur occasionally. Anti-HCV positive subjects may lose their antibodies and it remains to be seen whether those people are less infectious than persistently seropositive subjects.

This study was supported by the Danish Medical Research Council, the Danish Cancer Society, and the Danish Hospital Foundation for Medical Research.

1 Choo Q-L, Kuo G, Weiner AJ, Overby LR, Bradley DW, Houghton M. Isolation of a cDNA clone derived from a blood-borne non- $A$ non-B viral hepatitis genome. Science 1989;244:359-62.

$2 \mathrm{Kuo} \mathrm{G}$, Choo QL, Alter $\mathrm{HJ}$, et al. An assay for circulating antibodies to a major etiologic virus of human non-A non-B hepatitis. Science 1989;244:362-4.

3 Alter MJ, Coleman PJ, Alexander J, et al. Importance of heterosexual activity in the transmission of hepatitis $\mathrm{B}$ and non- $\mathrm{A}$, non- $\mathrm{B}$ hepatitis. FAMA 1989:262:1201-5.

4 Esteban JI, Esteban R, Viladomiu L, et al. Hepatitis $C$ virus antibodies among risk groups in Spain. Lancet 1989;ii:294-7.

5 Van der Poel CL, Reesink HW, Lelie PN, et al. Anti-hepatitis C antibodies and non-A, non-B post-transfusion hepatitis in the Netherlands. Lancet 1989 ii: $297-8$.

6 Roggendorf M, Deinhardt F, Rasshofer R, et al. Antibodies to hepatitis C virus. Lancet 1989; ii:324-5.

7 Noel L, Guerois C, Maisonneuve P, Verroust F, Laurian Y. Antibodies to hepatitis $C$ virus in haemophilia. Lancet 1989;ii:560.

8 Ludlum CA, Chapman D, Cohen B, Litton PA. Antibodies to hepatitis C virus in haemophilia. Lancet 1989;ii:560-1.

9 Alter MJ, Ahtone J, Weisfuse I, Starko K, Vacalis TD, Maynard JE. Hepatitis B virus transmission between heterosexuals. FAMA 1986;256:1307-10.

10 Melbye M, Biggar RJ, Ebbesen P, et al. Seroepidemiology of HTLV-III antibody in Danish homosexual men: prevalence, transmission, and disease antibody in Danish homosexual men:
outcome. Br Med 7 1984;289:573-5.

11 Melbye M, Biggar RJ, Ebbesen P, et al. Long-term seropositivity for human T-lymphotropic virus type III in homosexual men without the acquired immunodeficiency syndrome: development of immunologic and clinical abnormalities. Ann Intern Med 1986;104:496-500.

12 Becker NG, Melbye $M$. Use of a log-linear model to compute the empirical survival curve from interval-censored data, with application to data on tests for HIV positivity. Australian Journal of Statistics (in press).

13 Alter HJ, Purcell RH, Shih JW, et al. Detection of antibody to hepatitis $\mathrm{C}$ virus in prospectively followed transfusion recipients with active and chronic nonA non-B hepatitis. $N$ Engl $\mathcal{F}$ Med 1989;321:1494-1500.

14 Biggar RJ, Goedert JJ, Hoffnagle J. Accelerated loss of antibody to hepatitis B surface antigen among human immunodeficiency virus-infected, immunodeficient homosexual men. $N$ Engl f Med 1987;316:630-1.

(Accepted 18 May 1990)

The severity of infection with cryptosporidium varies, and immunocompetent patients may be asymptomatic. ${ }^{2}$ Usually there is an attack of watery, non-bloody diarrhoea with abdominal pain, vomiting, and fever. Temperatures of up to $38.3^{\circ} \mathrm{C}$ have been reported. ${ }^{2}$ The illness is self limiting, and symptoms

A 22 year old woman with $\beta$ thalassaemia major may be short lived or persist for many weeks. In immunocompromised subjects the illness is prolonged and debilitating and may be fatal.

\author{
Cryptosporidium has been increasingly recognised as a \\ cause of diarrhoea in both immunocompetent and \\ immunocompromised patients with the advent of \\ adequate staining techniques. It is a coccidian parasite, \\ which seems to be a single species able to infect a \\ range of animal hosts. ${ }^{1}$ In immunocompetent adults it \\ ranks third in the non-viral causes of gastrointestinal \\ symptoms after salmonella and campylobacter ${ }^{1}$ and in \\ patients with AIDS it is the commonest cause of \\ diarrhoea. \\ Correspondence to: \\ Dr Gledhill.

\section{Department of
Haematology, University \\ Department of School of Medicine, London WC1E 6HX Julia A Gledhill, MB, house physician John Porter, MRCPATH, consultant haematologist}

\section{Julia A Gledhill, John Porter}

\section{Case report} had been dependent on transfusions since birth and received desferrioxamine for iron overload. She had had a splenectomy at the age of 7 , and a test for HIV in March 1989 had yielded negative results. In June she presented to casualty with a 24 hour history of watery diarrhoea, colicky abdominal pain, vomiting, dizzi- 